\title{
Understanding a Proposed Model of Customer Loyalty Formation in $\mathrm{B} 2 \mathrm{C}$ e-Commerce
}

\author{
Saowakhon Homsud and Singha Chaveesuk
}

\begin{abstract}
Customer loyalty is a key determinant of B2C e-commerce survival, competitive advantage, and the long-term success. Loyalty can be divided into 2 types: attitudes loyalty, represented by customer purchase intention and customer's positive word of mouth, and behavioral loyalty, represented by customer repurchase intention. Based on literature review, it was found that customer loyalty antecedents included website quality, customer trust, perceived value of customer, and customer satisfaction. The purpose of this paper is to build a proposed model based on DeLone \& McLean e-commerce success model and adding related factor between website quality and customer loyalty, which consists of internet shopping value, customer trust, and customer satisfaction. This proposed model provides more understanding of the factors that influence customer loyalty in B2C e-commerce. It also presents hypotheses and develops a structural equation model for further empirical studies.
\end{abstract}

Index Terms-B2C e-commerce, e-commerce success model, website quality, customer loyalty.

\section{INTRODUCTION}

The expansion of infrastructure and rapid growing of internet user have caused many companies to operate in B2C e-commerce . They have used internet as the main channel of distribution of goods and services [1], which took them to reach their target groups easily, satisfy different services for customer, respond customer needs rapidly, reduce time and distance constraint, and reduce complexity of logistics [2].

B2C e-commerce's success and survival depend on customer loyalty. When customers become loyal, they will intent to purchase [3], [4], the more they purchase, the more they are willing to pay, and the more they recommend [5]. There are several researches emphasized on marketing theory and found that customer loyalty is influenced by customer satisfaction [6], [7], customer trust [7], [8], perceived value [9], and perceived quality [7].

However, carrying out threat and constraint has caused customers, who lacked trust, not to adopt B2C e-commerce [10]. In other words, negative attitude towards B2C e-commerce has caused them not to buy goods and services. B2C e-commerce should perceived customer confidence because it was important to improve its potential which affected customer willingness to participate in transaction of business [11].

Not only did B2C e-commerce lost customer acceptance, it could not also reflect customer desire which differed in

Manuscript received August 19, 2013; revised November 1, 2013.

The authors are with King Mongkut's Institute of Technology Ladkrabang, Bangkok, Thailand (e-mail: peung0321@gmail.com, singha@it.kmitl.ac.th). perceived shopping value. Some customers have set their goals and plans for shopping while some other customer has shopped for fun, without planning [12]-[14]. Differences in customers' perceived shopping value may affect differences in their desire. Therefore, it would be important to do the research on customer desire in order to find the way to satisfy them.

Several companies invest largely in e-commerce application, but they do not realize the evaluation of successful system [15]. For that reason, DeLone \& McLean [15] presented model which mentioned 3 dimensions of website quality - consisting of system quality, information quality, and service quality - which measure success in e-commerce.

Website is a key tool for B2C e-commerce's operation. In business, they need to control and develop it, particularly focused on its quality. If they have the high quality website, they will receive more confidence, satisfaction, and loyalty from their customers [7], [16]. It will also improve financial status of their business, which is a key for business survival and success [17]-[19].

The purpose of this paper is to build a proposed model of customer loyalty formation in B2C e-commerce, based on DeLone \& McLean e-commerce success model, and by presenting a structural equation model.

The research questions are listed as follows:

1) Which website quality factors do affect to customer trust?

2) Which website quality factors do affect to perceived value of customer which difference in value?

3) Which factors do affect to customer loyalty?

4) How to propose a model of customer loyalty for B2C e-commerce with based on DeLone \& McLean e-commerce success model

\section{HelPFul Hints}

\section{A. E-Commerce Success Model}

DeLoan \& McLean e-commerce success model [15] is adapted from DeLoan \& McLean IS success model [20] to measure challenges of the e-commerce. The model is related to 6 dimensions which include system quality, information quality, service quality, use, user satisfaction, and net benefits. The results revealed that the users would be satisfied and acknowledged the whole benefits when they perceived all three quality characteristics shown in the Fig. 1.

There are several researches used the DeLoan \& McLean e-commerce success model [15] as the model basis about the success of electronics business, as shown in Table I. 


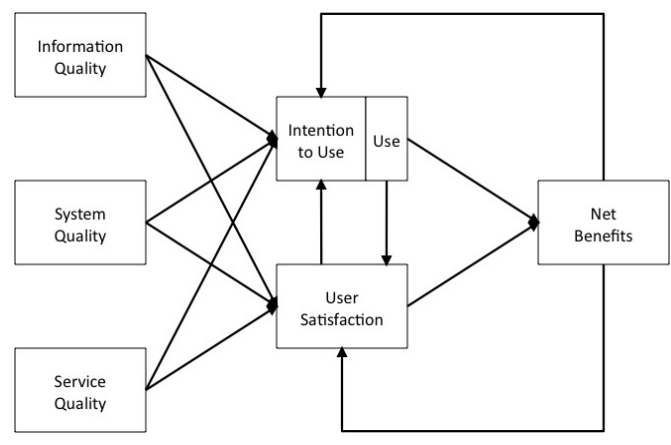

Fig. 1. DeLoan \& mclean e-commerce success model.

TABLE I: PREVIOUS STUdy BASEd ON DELOAN \& MCLean MODEL

\begin{tabular}{|c|c|c|}
\hline Author & Title & $\begin{array}{l}\text { Conseque } \\
\text { nces }\end{array}$ \\
\hline $\begin{array}{l}\text { Lee and } \\
\text { Chung [6] }\end{array}$ & $\begin{array}{l}\text { Understanding factors affecting } \\
\text { trust in and satisfaction with } \\
\text { mobile banking in Korea }\end{array}$ & $\begin{array}{l}\text { Customer } \\
\text { satisfactio } \\
\mathrm{n}\end{array}$ \\
\hline $\begin{array}{l}\text { Kim, Galliers, } \\
\text { Shin, Ryoo, } \\
\text { and Kim [9] }\end{array}$ & $\begin{array}{l}\text { Factors influencing Internet } \\
\text { shopping value and customer } \\
\text { repurchase intention. }\end{array}$ & $\begin{array}{l}\text { Intent to } \\
\text { repurchas } \\
\mathrm{e}\end{array}$ \\
\hline $\begin{array}{l}\text { Brown and } \\
\text { Jayakody [21] }\end{array}$ & $\begin{array}{l}\text { B2C e-Commerce Success: a } \\
\text { Test and Validation of a revised } \\
\text { Conceptual Model }\end{array}$ & $\begin{array}{l}\text { Continuan } \\
\text { ce } \\
\text { Intention }\end{array}$ \\
\hline $\begin{array}{l}\text { Lee, Choi, and } \\
\text { Kang [22] }\end{array}$ & $\begin{array}{l}\text { Formation of e-satisfaction and } \\
\text { repurchase intention: } \\
\text { Moderating roles of computer } \\
\text { self-efficacy and computer } \\
\text { anxiety }\end{array}$ & $\begin{array}{l}\text { Repurchas } \\
\text { e Intention }\end{array}$ \\
\hline $\begin{array}{l}\text { Keramati and } \\
\text { Salehi [23] }\end{array}$ & $\begin{array}{l}\text { Website success comparison in } \\
\text { the context of e-recruitment: An } \\
\text { analytic network process (ANP) } \\
\text { approach }\end{array}$ & $\begin{array}{l}\text { Use, User } \\
\text { satisfactio } \\
\mathrm{n}, \text { Net } \\
\text { benefits }\end{array}$ \\
\hline $\begin{array}{l}\text { Chen, } \\
\text { Rungrueng- } \\
\text { samrit, } \\
\text { Rajkumar and } \\
\text { Yen [24] }\end{array}$ & $\begin{array}{l}\text { Success of electronic commerce } \\
\text { Web sites: A Comparative study } \\
\text { in two countries }\end{array}$ & $\begin{array}{l}\text { Users } \\
\text { satisfactio } \\
\text { n, Attitude } \\
\text { toward the } \\
\text { site }\end{array}$ \\
\hline
\end{tabular}

\section{B. Website Quality}

There are several studies shown that the higher perceived website quality, the higher profitability [25]. It was also found that higher perceived website quality affected customer satisfaction, and customer satisfaction affected customer loyalty, respectively [7].

In order that the electronics business was successful, it was necessary to design and develop 3 dimensions of website quality [15], which included the system quality, information quality, and service quality

\section{1) System quality}

DeLone \& McLean [15] proposed that the system quality for measuring the characteristics of an e-commerce system was originated by several factors which included usability, availability, reliability, adaptability, and response time. In addition, security had significant for system quality, as e-commerce operated through the Internet. Moreover, Belanger, Hiller and Smith [26] proposed that the security and privacy was considered as one of the factor of system quality, and Chen, Rungruengsamrit, Rajkumar, and Yen [24] suggested the factors - usability and system availability - used for measuring the system quality. As a result, this study measured the system quality by using 3 factors which included the Usability, Security/Privacy, and System
Availability. The system quality would affect the customers in terms of their products purchase value [27], [28] and their trust [7], [21], [29].

For all reasons mentioned above, we proposed these hypotheses:

H1: System quality affected the positive results to the utilitarian shopping value.

$\mathrm{H} 2$ : System quality affected the positive results to the hedonic shopping value.

H3: System quality affected the positive results to the customer trust

\section{2) Information quality}

DeLone McLean IS success model [20], Lederer, Maupin, Sena, and Zhuan [30], and DeLone \& McLean [15] found that the quality of information was considered as the crucial factor which helped the users acknowledged the benefits. The information quality could be originated by several factors which included web contents. Those contents should be personalized, complete, relevant, and easy to understand. Kim, Kim, and Kandampully [31] suggested that convenience, web appearance, and entertainment had an impact on buying environment characteristics. Chen, Rungruengsamrit, Rajkumar, and Yen [24] identified the 3 factors - informativeness, organization, and entertainment used for measuring the information quality. Hence, this study used all 3 factors mentioned above to measure the information quality. The website designation could let the consumers acknowledge the information quality and let them be able to decide easily to buy more. The consumers would be perceived shopping value by Hedonic and Utilitarian type [32]; therefore, the information quality affected the consumption perceived the Hedonic value and Utilitarian value type [29] as well as affecting the customer trust [6], [29], [33].

For all reasons mentioned above, we proposed these hypotheses:

H4: Information quality affected the positive results to the utilitarian shopping value.

H5: Information quality affected the positive results to the hedonic shopping value.

H6: Information quality affected the positive results to the customer trust.

\section{3) Service quality}

DeLone \& McLean [15] and Molla and Licker [34] added the service quality into the model to be in accordance with and appropriate to be used as the model of electronic commerce. The service quality could be originated by several factors which included reliability, responsiveness, assurance and empathy. Yoo and Donthy [35] developed SITEQUAL scale for measuring perceived quality of online shopping. They also found that perceived quality originated from web design, customer service, assurance and order management. Moreover, perceived quality would influence customer satisfaction, and customer satisfaction would influence customer loyalty, respectively. The research of Chen, Rungruengsamrit, Rajkumar, and Yen [24] identified the 2 factors - trust and empathy - used for measuring the service quality. This study also used the assurance and empathy for measuring the service quality. Kim, Galliers, Shin, Ryoo, and 
Kim [10] indicated that the service quality affected both Utilitarian and Hedonic value, and it also affected the customer trust [6].

For all reasons mentioned above, we propose these hypotheses:

H7: Service quality affected the positive results to the utilitarian shopping value.

H8: Service quality affected the positive results to the hedonic shopping value.

H9: Service quality affected the positive results to the customer trust

\section{Customer Trust}

Trust means the expectation made by the customers; their needs would be responded by the sellers [36]; therefore trust was considered as one of the crucial factors affecting the success of electronics business. Molla and Licker [34] developed the e-commerce success model based on the DeLoan \& McLean IS success model [20] by adding 2 components - service quality and trust - into the model. The consumers would be trusted when they acknowledged the safety and privacy [11], [37], and the quality acknowledgement too [7], [8], [17], [21], [33]. There were recent researches on the customer trust, for example, the research of Luarn and Lin [38] which found that the more the customers felt trust, the more they needed to buy goods. Hence, this could be indicated that trust would affect the customer satisfaction [7], [21], [33], [39], [40] and it would affect the customer loyalty too [8], [9], [16], [36], [40]-[42].

For all reasons mentioned above, we propose these hypotheses:

H10: Customer trust affected the positive results to the customer satisfaction.

H11: Customer trust affected the positive results to the customer loyalty.

\section{Internet Shopping Value}

Moe [13] categorized the customer purchasing behavior into 2 types - the Goal-Oriented and the Exploration -Oriented. The goal-oriented customers would plan in advance what they needed to buy [12], and they intended to collect information of products they needed to buy first [13], [43], they also needed the quickness to search the information [32], they selected the products with certain goals, called utilitarian shopping value [6], [14], [32]. Whereas the exploration-oriented customers would buy the products without planning in advance, they needed browsing the information for amusement, entertainment, or for escaping the routine work [32], called hedonic shopping value [6], [14] [32]. However, the experiences of product purchase would make the consumers acknowledge both utilitarian shopping value and hedonic shopping value. But it would be different in terms of quantity of acknowledgement [11], [44], depending on the difference of specific characteristics of consumers. Both types of behavior would affect the purchase selection methods which were different from each other [45].

Perceived value of shopping experience satisfied customer [46]. Babin, Darden, and Griffin [12] and Lee, Kim, and Fairhurst [47] indicated that both utilitarian and hedonic shopping value influenced the customer satisfaction. In addition, previous research had shown that shopping value influenced satisfaction [46]-[48]. Also, Babin, Darden, and Griffin [12], Bridges and Florsheim [27], and Chiagouris and Ray [49] suggested that both shopping values would influence the repeat purchasing behavior. Moreover, Jones, Michael, Reynolds, and Arnold [48] suggested that both utilitarian and hedonic shopping value had influence over positive word of mouth. Repurchasing and positive word of mouth are behavior indicating loyalty.

For all reasons mentioned above, we propose these hypotheses:

H12: Utilitarian shopping value affected the positive results to the customer satisfaction.

H13: Hedonic shopping value affected the positive results to the customer satisfaction.

H14: Utilitarian shopping value affected the positive results to the customer loyalty.

H15: Hedonic shopping value affected the positive results to the customer loyalty.

\section{E. Customer Satisfaction}

The customer satisfaction was originated by the differences between the expectation of the customers and what they got [50]. If the customers got what they needed and in accordance with their expectation, they would be satisfied. The customers would rather expect to buy goods online rather than offline [51]. The organizations should emphasize the satisfaction created for customers because it was regarded as the crucial backbone which would cause the loyalty [52]. According to Table II and the literature review, there were a lot of researches indicated that customer satisfaction has strongly affected the positive results of the loyalty; such indications were supported by Kim, Galliers, Shin, Ryoo, and Kim [9], Flavian, Guinaliu and Gurrea [16], Chen [39], Balabanis, Reynolds, and Simintiras [53], Martinez and Bosque [54], Kim, Jin, and Swinney [55], and Safa and Ismail [56]. In addition, Carpenter [46] suggested that satisfaction leads to positive word of mouth and purchase intentions in the future. However, the customers would be satisfied when they perceived value [9] and could feel the trust [33], [39], [40]. According to this study, the customer satisfaction would be replaced the user satisfaction which was the component of DeLone \& McLean e-commerce success model [15].

For all reasons mentioned above, we propose these hypotheses:

H16: Customer satisfaction affected the positive results to the customer loyalty.

\section{F. Customer Loyalty}

The customer loyalty is the crucial key for leading the organizations to reach the success [18], [19]. Cyr, Kindra, and Dash [57] suggested that e-loyalty was defined as the loyalty intended and planned by the electronics service users to make the decision of buying goods and services from the websites at that time, or in the future. Loyalty could be divided into 2 types, which included attitudinal loyalty and behavioral loyalty [58]. Both of the loyalties mentioned were different from each other [3], [4]. For behavioral loyalty, the customers would express their behavior in terms of repeat buying. However, it was probably that the consumers who 
bought repeatedly might not have any other alternatives, or they needed to save the cost, had a little time for searching beneficial information, or it might be that the website had the interesting sales promotion [54]. Hence, it can be said that the repeat buying behavior may not be the real loyalty. While the attitudinal loyalty was expressed by the purchasing behavior and positive word of mouth because the customers had good attitudes towards the organizations and felt affiliated to their products. Although the customers intended to purchase the goods and promoted by word of mouth communications, it might be possible that they would not buy repeatedly in a later time [52], [59], thus the organizations might not get the profits from the attitudinal loyalty. For the reasons mentioned, it could be suggested that the organizations should focus on both types of customer loyalty and should measure the loyalty in both views [5]. The previous study of customer loyalty as shown in Table II.

TABLE II: CRITICAL FACTORS IN LOYALTY

\begin{tabular}{|c|c|c|}
\hline Author & Title & Factors \\
\hline Shin, Chung, Oh, and Lee [7] & $\begin{array}{l}\text { The effect of site quality on repurchase intention in Internet } \\
\text { shopping through mediating variables: The case of university } \\
\text { students in South Korea }\end{array}$ & $\begin{array}{l}\text { Site quality, Customer satisfaction, Customer } \\
\text { trust, and Customer commitment }\end{array}$ \\
\hline $\begin{array}{l}\text { Flavian, Guinaliu, and Gurrea } \\
{[16]}\end{array}$ & $\begin{array}{l}\text { The role played by perceived usability, satisfaction and consumer } \\
\text { trust on website loyalty }\end{array}$ & $\begin{array}{l}\text { Perceived website usability, trust, and } \\
\text { Satisfaction }\end{array}$ \\
\hline Lee, Choi, and Kang [22] & $\begin{array}{l}\text { Formation of e-satisfaction and repurchase intention: Moderating } \\
\text { roles of computer self-efficacy and computer anxiety }\end{array}$ & $\begin{array}{l}\text { Website Information Satisfaction, Website } \\
\text { System Satisfaction, Efficiency, Fulfillment, } \\
\text { Overall e-Service Quality, and e-Satisfaction }\end{array}$ \\
\hline Martinez, and Bosque [54] & $\begin{array}{l}\text { CSR and customer loyalty: The roles of trust, customer } \\
\text { identification with the company and satisfaction }\end{array}$ & $\begin{array}{l}\text { Corporate Social Responsibility, Customer } \\
\text { identification with the company, Consumer } \\
\text { trust, and Customer satisfaction, }\end{array}$ \\
\hline Safa and Ismail [56] & A customer loyalty formative model in electronic commerce & $\begin{array}{l}\text { Technology Factors, Organizational Factors, } \\
\text { Customer Factors, E-satisfaction, and E-trust }\end{array}$ \\
\hline Chang and Chen [60] & $\begin{array}{l}\text { The impact of customer interface quality, satisfaction and switching } \\
\text { costs on e-loyalty: Internet experience as a moderator }\end{array}$ & $\begin{array}{l}\text { Customization, Interactivity, Convenience, } \\
\text { Character, Switching Costs, and Customer } \\
\text { Satisfaction }\end{array}$ \\
\hline $\begin{array}{l}\text { Toufaily, Ricard, and Perrien } \\
\text { [61] }\end{array}$ & $\begin{array}{l}\text { Customer loyalty to a commercial website: Descriptive } \\
\text { meta-analysis of the empirical literature and proposal of an } \\
\text { integrative model }\end{array}$ & $\begin{array}{l}\text { Customer Characteristics, Environmental } \\
\text { characteristics, Product/Service attributes, } \\
\text { Company/Retailer characteristics, and } \\
\text { Website characteristics }\end{array}$ \\
\hline $\begin{array}{l}\text { Jaiswal, Niraj, and Venugopal } \\
\text { [62] }\end{array}$ & $\begin{array}{l}\text { Context-geneal and Context-specific Determinants of Online } \\
\text { Satisfaction and Loyalty for Commerce and Content Sites }\end{array}$ & $\begin{array}{l}\text { Web community, privacy, web expertise, } \\
\text { security, fulfillment/Reliability, and customer } \\
\text { satisfaction }\end{array}$ \\
\hline $\begin{array}{l}\text { Salehi, Abdollahbeig, } \\
\text { Langroudi, and Forouz Salehi } \\
\text { [63] }\end{array}$ & $\begin{array}{l}\text { The Impact of Website Information Convenience On E-Commerce } \\
\text { Success Of Companies }\end{array}$ & $\begin{array}{l}\text { Type and variety of information exists in } \\
\text { websites, website design, personalization, } \\
\text { and website information convenience }\end{array}$ \\
\hline Pan, Sheng, and Xie [64] & $\begin{array}{l}\text { Antecedents of customer loyalty: An empirical synthesis and } \\
\text { reexamination }\end{array}$ & $\begin{array}{l}\text { Customer related factors (customer } \\
\text { satisfaction, trust, psychological } \\
\text { commitment, Loyalty program membership) } \\
\text { and Product related factors (Perceived value, } \\
\text { product quality, perceived fairness, } \\
\text { Switching costs, Brand reputation) }\end{array}$ \\
\hline Chang, and Chen [65] & $\begin{array}{l}\text { Consumer perception of interface quality, security, and loyalty in } \\
\text { electronic commerce }\end{array}$ & $\begin{array}{l}\text { Interface quality, Perceived Security, } \\
\text { Switching Costs, and Customer Satisfaction }\end{array}$ \\
\hline $\begin{array}{l}\text { Casalo, Flavian, and Guinaliu } \\
{[66]}\end{array}$ & $\begin{array}{l}\text { The role of perceived usability, reputation, satisfaction and } \\
\text { consumer familiarity on the website loyalty formation process }\end{array}$ & Usability, Satisfaction, and Reputation \\
\hline
\end{tabular}

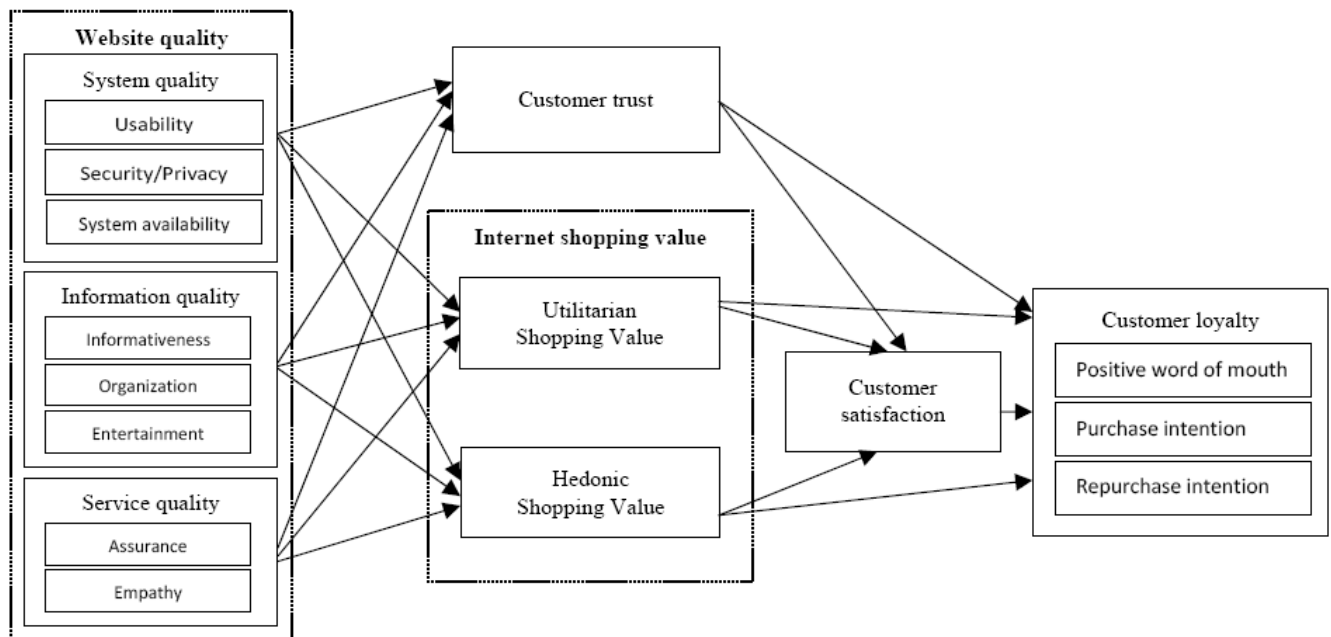

Fig. 2. The proposed model. 


\section{PROPOSED MODEL}

As for Table II, it is shown about critical factors affecting to loyalty consisted of customer satisfaction, trust, and website quality. Therefore, it can conclude that the factors affecting both direct and indirect results through the both types of loyalty were originated by 4 main antecedents including customer satisfaction, customer trust, shopping value, and quality [5], [6]. For this study, the customer loyalty would be used to replace the net benefit which was the dimension of DeLone \& McLean e-commerce success model.

Based on literature reviewing and provides hypotheses for customer loyalty formation in $\mathrm{B} 2 \mathrm{C}$ e-commerce is proposed model in Fig. 2.

\section{CONCLUSIONS}

Business cannot survive without customer loyalty. Hence, customer loyalty is the key determinant for B2C e-commerce success. Moreover, customer loyalty in B2C e-commerce derives from website quality, customer trust, perceived shopping value, and perceived quality.

It is necessary for business to control and develop website quality, as website is an important tool for driving B2C e-commerce. Furthermore, if customers perceived website quality, they will trust and perceived shopping value. Then, trust and perceived shopping value will affect customer loyalty, which also influence survival, competitiveness, advantage, and success.

This paper presents a proposed model of customer loyalty formation in B2C e-commerce. It is based on DeLone \& McLean e-commerce success model, which mentioned 3 dimensions, consisting of system quality, information quality, and service quality; and adding related factors including customer trust and internet shopping value (utilitarian and hedonic shopping value) dimensions in proposed model. This proposed model provides a conceptual framework for further empirical studies of customer loyalty formation in $\mathrm{B} 2 \mathrm{C}$ e-commerce.

\section{REFERENCES}

[1] P. L. To, C. Liao, and T. H. Lin, "Shopping motivations on internet: A study based on utilitarian and hedonic value," Technovation, vol. 27, pp. 774-787, December 2007.

[2] Y. M. Kim and K. Y. Shim, "The influence of internet shopping mall characteristics and user traits on purchase intent," Irish Marketing Review and Journal of Korean Academy of Marketing Science, vol. 15, pp. 25-34, 2002.

[3] A. Chaudhuri and M. B. Holbrook, "The chain of effects from brand trust and brand affect to brand performance: the role of brand loyalty," Journal of Marketing, vol. 65, pp. 81-93, 2001.

[4] H. Han, Y. Kimb, and E. Kima, "Cognitive, affective, conative, and action loyalty: Testing the impact of inertia," International Journal of Hospitality Management, vol. 30, pp. 1108-1119, 2011.

[5] L. Harris and M. Goode, "The four levels of loyalty and the pivotal role of trust: A study of online service dynamic," Journal of Retailing, vol. 80, pp. 139-158, 2004.

[6] K. C. Lee and N. Chung, "Understanding factors affecting trust in and satisfaction with mobile banking in Korea: A modified DeLone and McLean's model perspective," Interacting with Computers, vol. 21, pp. 385-392, 2009.

[7] J. I. Shin, K. H. Chung, J. S. Oh, and C. W. Lee, "The effect of site quality on repurchase intention in Internet shopping through mediating variables: The case of university students in South Korea,"
International Journal of Information Management, vol. 33, pp. 453-463, 2013.

[8] A. Chaudhuri and M. B. Holbrook, "The chain effects from brand trust and brand affect to brand performance: The role of brand loyalty," Journal of Marketing, vol. 65, pp. 81-93, April 2001.

[9] C. Kim, R. D. Galliers, N. Shin, J. Ryoo, and J. Kim, "Factors influencing internet shopping value and customer repurchase intention," Electronic Commerce Research and Applications, vol. 11, pp. 374-387, July-August 2012.

[10] D. L. Hoffman, T. P. Novak, and M. A. Peralta, "Building consumer trust online," Communications of the ACM, vol. 42, pp. 80-85, 1999.

[11] D. Gefen, "E-Commerce: The role of familiarity and trust," The International Journal of Management Science, vol. 28, pp. 725-737, 2000.

[12] J. Babin, R. Darden, and M Griffin, "Work and/or fun: Measuring hedonic and utilitarian shopping value," Journal of Consumer Research, vol. 20, pp. 644-657, March 1994.

[13] W. W. Moe, "Buying, searching, or browsing: Differentiating between online shoppers using in-store navigational click stream," Journal of Consumer Psychology, vol. 13, pp. 29-39, 2003.

[14] Y. J. Wang, S. Michaels, and J. Wei, "Aesthetics and the online shopping environment: Understanding consumer responses," Journal of Retailing, vol. 87, pp. 46-58, March 2011.

[15] W. H. DeLone and E. R. McLean, "Measuring e-Commerce success: Applying the DeLone and McLean information systems success model," International Journal of Electronic Commerce, vol. 9, pp. 31-47, 2004

[16] C. Flavian, M. Guinaliu, and R. Gurrea, "The role played by perceived usability, satisfaction and consumer trust on website loyalty," Information and Management, vol. 43, pp. 1-14, 2006.

[17] H. H. Chang and S. W. Chen, "Consumer perception of interface quality, security, and loyalty in electronic commerce," Information and Management, vol. 46, pp. 411-417, October 2009.

[18] C. Chen and C. Cheng, "Understanding consumer intention in online shopping: A respecification and validation of the DeLone and McLean model," Behaviour and Information Technology, vol. 28, pp. 335-345, 2009.

[19] H. Kuan, G. Bock, and V. Vathanophas, "Comparing the effects of website quality on customer initial purchase and continued purchase at e-commerce websites," Behavior and Information Technology, vol. 27, pp. 3-16, 2008.

[20] W. H. DeLone and E. R. McLean, "Information systems success: The quest for the dependent variable," Information Systems Research, vol. 3, pp. 60-95, 1992.

[21] I. Brown and R. Jayakody, "B2C e-Commerce success: A test and validation of a revised conceptual model," Electronic Journal Information System Evaluation, vol. 11, pp. 167-184, 2008.

[22] H. Lee, S. Y. Choi, and Y. S. Kang, "Formation of e-satisfaction and repurchase intention: Moderating roles of computer self-efficacy and computer anxiety," Expert Systems with Application, vol. 36, pp. 7848-7859, May 2009.

[23] A. Keramati, and M. Salehi, "Website success comparison in the context of e-recruitment: An analytic network process (ANP) approach," Applied Soft Computing, vol. 13, pp. 173-180, January 2013.

[24] J. V. Chen, D. Rungruengsamrit, T. M. Rajkumar, and D. C. Yen. "Success of electronic commerce web sites: A comparative study in two countries," Information and Management, vol. 50, pp. 344-355, September 2013

[25] E. Cristobal, C. Flavian, and M. Guinaliu, "Perceived E-Service Quality (PeSQ): Measurement validation and effects on consumer satisfaction and web site loyalty," Managing Service Quality, vol. 17, pp. 317-340, 2007.

[26] F. Belanger, J. S. Hiller, and W. J. Smith, "Trustworthiness in electronic commerce: the role of privacy, security, and site attributes," The Journal of Strategic Information Systems, vol. 11, pp. 245-270, 2002.

[27] E. Bridges and R. Florsheim, "Hedonic and utilitarian shopping goals The online experience," Journal of Business Research, vol. 61, pp. 309-314, April 2008.

[28] J. W. Overby and E. J. Lee, "The effects of utilitarian and hedonic online shopping value on consumer preference and intentions," Journal of Business Research, vol. 59, pp. 1160-1166, October 2006.

[29] D. Gefen, E. Karahanna, and D. W. Straub, "Trust and TAM in online shopping: An integrated model," MIS Quarterly, vol. 27, pp. 51-90, March 2003.

[30] A. L. Lederer, D. J. Maupin, M. P. Sena, and Y. Zhuang, "The technology acceptance model and the World Wide Web," Decision Support Systems, vol. 29, pp. 269-282, 2000. 
[31] J. H. Kim, M. J. Kim, and J. Kandampully, "Buying environment characteristics in the context of e-service," European Journal of Marketing, vol. 43, pp. 118-1204, 2009.

[32] A. I. Nicolaou and D. H. McKnight, "Perceived information quality in data exchanges: Effects on risk, trust, and intention to use," Information Systems Research, vol. 4, pp. 332-351, 2006.

[33] E. S. Kassim, S. F. A. K. Jailani, H. Hairuddin, and N. H. Zamzuri, "Information system acceptance and user satisfaction: The mediating role of trust," Procedia - Social and Behavioral Sciences, vol. 57, pp. 412-418, October 2012.

[34] A. Molla and P. S. Licker, "E-Commerce systems success: An attempt to extend and respecify The DeLone and Maclean model of IS success," Journal of Electronic Commerce Research, vol. 2, pp. 131-141, 2001.

[35] B. Yoo and N. Donthu, "Developing a scale to measure the perceived quality of an Internet shopping site (SITEQUAL)," Quarterly Journal of Electronic Commerce, vol. 2, pp. 31-36, 2001.

[36] D. Sirdeshmukh, J. Singh, and B. Sabol, "Consumer trust, value and loyalty in relational exchanges," Journal of Marketing, vol. 66, pp. 15-37, January 2002.

[37] S. M. Furnell and T. Karweni, "Security implications of electronic commerce: A survey of consumers and business," Electronic Networking Application and Policy, vol. 9, pp. 372-382, 1999.

[38] P. Luarn and H. Lin, "A customer loyalty model for e-service context," Journal of Electronic Commerce Research, vol. 4 pp. 156-167, 2003

[39] S. C. Chen, "The customer satisfaction-loyalty relation in an interactive e-service setting: The mediators," Journal of Retailing and Consumer Services, vol. 19, pp. 202-210, March 2012.

[40] K. Namasivayam and P. Guchait, "The role of contingent self-esteem and trust in consumer satisfaction: Examining perceived control and fairness as predictors," International Journal of Hospitality Management, vol. 33, pp. 184-195, June 2013.

[41] H. W. Kim, Y. Xu, and S. Gupta, "Which is more important in internet shopping, perceived price or trust?" Electronic Commerce Research and Applications, vol. 11, pp. 241-252, May-June 2012.

[42] H. H. Kuan and G. W. Bock, "Trust transference in brick and click retailers: An investigation of the before-online-visit phase," Information \& Management, vol. 44, pp. 175-187, March 2007.

[43] C. Janiszewski, "The Influence of display characteristics on visual exploratory search behavior," Journal of Consumer Research, vol. 25, pp. 290-301, 1998

[44] B. J. Babin and W. R. Darden, "Consumer self-regulation in a retail environment," Journal of Retailing, vol. 71, pp. 47-70, 1995.

[45] D. Scarpi, "Work and fun on the internet: The effects of utilitarianism and hedonism online," Journal of Interactive Marketing, vol. 26, pp. $53-67,2012$.

[46] J. M. Carpenter, "Consumer shopping value, satisfaction and loyalty in discount retailing," Journal of Retailing and Consumer Services, vol. 15 , pp. 358-363, 2008

[47] M. Y. Lee, Y. K. Kim, and A. Fairhurst, Shopping value in online auctions: Their antecedents and outcomes, 2009.

[48] J. A. Michael, K. E. Reynolds, and M. J. Arnold, "Hedonic and utilitarian shopping value: Investigating differential effects on retail outcomes," Journal of Business Research, vol. 59, pp. 974-981, 2006.

[49] L. Chiagouris and I. Ray, "Customers on the web are not all created equal: The moderating role of internet shopping experience," The International Review of Retail, Distribution and Consumer Research, vol. 20, pp. 251-271, 2010.

[50] A. Gustafsson, M. D. Johnson, and I. Roos, "The effects of customer satisfaction, relationship commitment dimensions, and triggers on customer retention," Journal of Marketing, vol. 69, pp. 210-218, October 2005

[51] V. Shankar, A. K. Smith, and A. Rangaswamy, "Customer satisfaction and loyalty in online and offline environments," International Journal of Research in Marketing, vol. 20, pp. 153-175, June 2003.

[52] R. L. Oliver, A Behavioral Perspective on the Consumer, New York, NY.: Irwin/McGraw-Hill, 1997

[53] G. Balabanis, N. Reynolds, and A. Simintiras, "Bases of e-store loyalty: Perceived switching barriers and satisfaction," Journal of Business Research, vol. 59, pp. 214-224, February 2006.

[54] P. Martizez and L. R. Bosque, "CSR and customer loyalty: The roles of trust, customer identification with the company and satisfaction,"
International Journal of Hospitality Management, vol. 35, pp. 89-99, December 2013.

[55] J. Kim, B. Jin, and J. L. Swinney, "The role of etail quality, e-satisfaction and e-trust in online loyalty development process," Journal of retailing and consumer Services, vol. 16, pp. 239-247, July 2009.

[56] N. S. Safa and M. A. Ismail, "A customer loyalty formative model in electronic commerce," Economic Modeling, vol. 35, pp. 559-564, September 2013

[57] D. Cyr, G. S. Kindra, and S. Dash, "Web site design, trust, satisfaction, and e-loyalty: The Indian experience," Online Information Review, vol 32, pp. 773-790, 2008

[58] K. L. Keller, "Conceptualizing, measuring, and managing customer-based brand equity," Journal of Marketing, vol. 57, pp. 1-12, January 1993.

[59] A. Dick and K. Basu, "Customer loyalty: Towards an integrated framework," Journal of the Academy of Marketing Science, vol. 22, pp. 99-113, 1994

[60] H. H. Chang and S. W. Chen, "The impact of customer interface quality, satisfaction and switching costs on e-loyalty: Internet experience as a moderator," Journal Computers in Human Behavior, vol. 24, pp. 2927-2944, September 2008.

[61] E. Toufaily, L. Ricard, and J. Perrien, "Customer loyalty to a commercial website: Descriptive meta-analysis of the empirical literature and proposal of an integrative model," Journal of Business Research, vol. 66, pp. 1436-1447, September 2013.

[62] A. K. Jaiswal, R. Niraj, and P. Venugopal, "Context-Geneal and context-specific determinants of online satisfaction and loyalty for commerce and content sites," Journal of Interactive Marketing, vol. 24, pp. 222-238, August 2010.

[63] F. Salehi, B. Abdollahbeigi, A. C. Langroudi, and F. Salehi, "The impact of website information convenience on e-commerce success of companies," Procedia - Social and Behavior Sciences, vol. 57, pp. 381-387, October 2012.

[64] Y. Pan, S. Sheng, and F. T. Xie, "Antecedents of customer loyalty: An empirical synthesis and reexamination," Journal of Retailing and Consumer Services, vol. 19, pp. 150-158, January 2012

[65] H. H. Chang and S. W. Chen, "Consumer perception of interface quality, security, and loyalty in electronic commerce," Information \& Management, vol. 46, pp. 411-417, October 2009.

[66] L. Casalo, C. Flavian, and M. Guinaliu, "The role of perceived usability, reputation, satisfaction and consumer familiarity on the website loyalty formation process," Journal Computers in Human Behavior, vol. 24, pp. 325-345, March 2008.

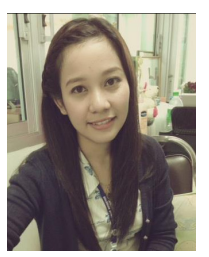

Saowakhon Homsud is studying master degree in information technology and Management Program at Faculty of Information Technology, King Mongkut's Institute of Technology Ladkrabang, Bangkok, Thailand. She graduated bachelor degree in Marketing at Ratjabhat Nakorn Si Thammarat, Thailand. She is currently working as computer teacher at Hua-Hin vithayalai school, Prachubkirikhan, Thailand. Before current job, She worked at Walailak University, Nakorn Si Thammarat, Thailand. Her current and previous research interests are about e-commerce, marketing, and e-education.

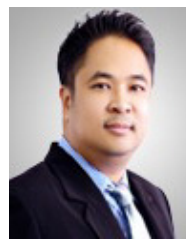

Singha Chaveesuk has a Ph.D. in information systems from Victoria University (Australia). He also graduated M.S. in information management from University of Akron (USA), M.B.A. in Management from Cleveland State University (USA), B.B.A. in Marketing from Thammasart University (Thailand), and B.S. in Computer Science from Ramkhamhaeng University (Thailand). He is currently working as lecturer at Faculty of Information Technology, King Mongkut's Institute of Technology Ladkrabang, Bangkok, Thailand. His research interests include Enterprise Resource Planning, Business Intelligence, Technological Innovation Adoption, and Business Process Modeling. 